\title{
Research on Development Status and Design Trend of Consumer-grade Disinfectant and Sterilizing Products with Reference to Emotional Design
}

\author{
Wanheng Zhong \\ The Guangzhou Academy of Fine Arts, Guangzhou 510200, Guangdong, China \\ Email: 1669839180@qq.com
}

\begin{abstract}
In the global fight against COVID-19 in 2020, tremendous changes have taken place in people's living habits and health awareness. Disinfection has been considered as a significant sanitary step in people's routine life and public places. In this thesis, the characteristics and current status of consumer-grade disinfectant and sterilizing products will be expounded, and the development trend of consumer-grade disinfectant and sterilizing products will be explored from three levels of user experience. Disinfectant and sterilizing products are classified into chemical agents and hardware for disinfection and sterilization. With reference to emotional design theory, this thesis chiefly elaborates the hardware part. By building an analysis model of emotional design and exploring cutting-edge design cases, it is drawn that consumer-grade disinfectant and sterilizing products boast diversified, intelligent, home-based and emotional trends, which is of enormous significance to enhance the systematic design theory and methods of consumer-grade disinfectant and sterilizing products.

Keywords: emotional design, consumer-grade products, disinfectant and sterilizing products, three levels of user experience, design trend
\end{abstract}

\section{Introduction}

From the outbreak of COVID-19 to October 2020, the cumulative number of confirmed infections on a global scale was more than 37 million, and the death toll was over 1 million. COVID-19 chiefly spreads through droplets, contact and aerosol, so it is particularly crucial to adopt personal protective measures and disinfection and sterilization measures in order to prevent COVID-19. Before the outbreak, disinfectant and sterilizing products were not attached much importance by the general public. Previously, domestic disinfectant and sterilizing products were chiefly applied in medical treatment, plant protection and pest disinfection and sterilization, and the public rarely come into contact with such products in their daily life. Throughout the epidemic, the demand for disinfectant and sterilizing products and drugs soared. Thereafter, life gradually resumed to its original state, but health habits may be influenced in the long run. Despite that WHO and CDC all over the world have offered detailed guidance on the correct use of disinfectants in the pandemic disease, there is basically no necessary guidance on the use of disinfection and sterilization equipment and appliances.

\section{Concept and classification of consumer-grade disinfectant and sterilizing products}

\subsection{Concept of consumer-grade disinfectant and sterilizing products}

Disinfection and sterilization is intended to eliminate most microorganisms and reduce the number of common viruses and bacteria to a safe level by means of chemicals or other methods with a view to ensure people's health. Disinfectant and sterilizing products are classified into chemical agents and hardware for disinfection and sterilization. This thesis chiefly elaborates the hardware part. Consumer-grade products refer to products that can be afforded by mass consumers, generally products with prices lower than those of commercial or professional grade, and also products designed for consumers. Consumer-grade disinfectant and sterilizing products refer to disinfectant and sterilizing products that are generally applied by households or individuals. The formation and development of the concept of disinfection against germs in modern times has advanced step by step precisely in the development of modern medicine, microbiology, epidemiology, chemistry, physics and other related disciplines. Ignace Semmelweis, a Hungarian obstetrician, is deemed as a pioneer in the promotion of disinfection methods. During his work in Vienna General Hospital, he required doctors to wash their hands carefully with bleaching powder before delivering babies. In 1867, Joseph Lister officially published his own surgical disinfection method using carbolic acid as disinfectant in the British medical journal Lancet. Carbonic acid originally applied by Lister is irritating and corrosive to human body, and it is not an ideal disinfectant due to its enormous toxicity. 
Thus, it has also been replaced by $75 \%$ alcohol. These series of improvements have finally contributed to the formation of modern disinfection methods we have seen so far.

\subsection{Classification of consumer-grade disinfectant and sterilizing products}

COVID-19 is chiefly airborne through close contact between people, respiratory droplets and aerosols. The best way to prevent the infection of COVID-19 is to cut off the transmission channels of sources of the disease. The commonly used measures to cut off the transmission channels are disinfection and sterilization and isolation. Currently, consumer-grade disinfectant and sterilizing products can be classified into chemical disinfection and sterilization, hightemperature disinfection and sterilization, radiation disinfection and sterilization, biological disinfection and sterilization and mechanical disinfection and sterilization, as presented in Table 1. Based on the different objects of disinfection and sterilization, disinfectant and sterilizing products can be classified into environmental disinfection and sterilization, disinfection and sterilization of articles, disinfection and sterilization of food and disinfection and sterilization of human body; therein, in respect of environmental disinfection and sterilization, chemical disinfection and sterilization, radiation disinfection and sterilization and mechanical disinfection and sterilization can be adopted; with regard to disinfection and sterilization of articles, chemical disinfection and sterilization, high-temperature disinfection and sterilization, biological disinfection and sterilization and mechanical disinfection and sterilization can be applied; as for disinfection and sterilization of food, high-temperature disinfection and sterilization and biological disinfection and sterilization can be employed; as far as disinfection and sterilization of human body, chemical disinfection and sterilization and mechanical disinfection and sterilization can be applied.

Table 1. Classification, advantages and disadvantages of disinfection and sterilization methods

\begin{tabular}{|c|c|c|c|c|}
\hline Method & Mode & Medium & Advantages & Disadvantages \\
\hline $\begin{array}{l}\text { Chemical disinfection } \\
\text { and sterilization }\end{array}$ & $\begin{array}{l}\text { Soak, wipe, spray or } \\
\text { aerosol spray, steam } \\
\text { and fumigate }\end{array}$ & $\begin{array}{l}\text { Chemical disinfectant drugs } \\
\text { (disinfectants containing chlorine, } \\
\text { peroxides, aldehydes, iodine, } \\
\text { phenols, ethylene oxide, biguanides } \\
\text { and quaternary ammonium salts) }\end{array}$ & $\begin{array}{l}\text { Simple and flexible use } \\
\text { and large processing area }\end{array}$ & $\begin{array}{c}\text { It causes environmental } \\
\text { pollution and some } \\
\text { chemicals are harmful to } \\
\text { human body }\end{array}$ \\
\hline $\begin{array}{l}\text { High-temperature } \\
\text { disinfection and } \\
\text { sterilization }\end{array}$ & $\begin{array}{l}\text { Boil, steam, roast, } \\
\text { microwave }\end{array}$ & $\begin{array}{l}\text { High temperature steam, hot water, } \\
\text { fire }\end{array}$ & $\begin{array}{l}\text { Complete disinfection } \\
\text { and sterilization and } \\
\text { environmental protection }\end{array}$ & $\begin{array}{l}\text { There are restrictions } \\
\text { on the material of } \\
\text { articles and the } \\
\text { human environment is } \\
\text { unavailable }\end{array}$ \\
\hline $\begin{array}{l}\text { Radiation disinfection } \\
\text { and sterilization }\end{array}$ & Irradiate, radiate & $\begin{array}{c}\text { Ultraviolet rays and ultrasonic } \\
\text { waves }\end{array}$ & $\begin{array}{l}\text { Fast speed, killing a large } \\
\text { number of microorganisms }\end{array}$ & $\begin{array}{l}\text { Ultraviolet rays are } \\
\text { harmful to human body, } \\
\text { and it is hard to satisfy } \\
\text { the requirements of } \\
\text { complete disinfection } \\
\text { and sterilization }\end{array}$ \\
\hline $\begin{array}{l}\text { Biological disinfection } \\
\text { and sterilization }\end{array}$ & $\begin{array}{l}\text { Reproduce, ferment } \\
\text { and filter }\end{array}$ & $\begin{array}{l}\text { Kill or remove pathogenic } \\
\text { microorganisms with a certain } \\
\text { organism }\end{array}$ & $\begin{array}{l}\text { The process is slow and } \\
\text { the effect is not entirely } \\
\text { reliable }\end{array}$ & $\begin{array}{c}\text { Generally, it exerts no } \\
\text { killing effect on bacterial } \\
\text { spores and is harmful to } \\
\text { human body }\end{array}$ \\
\hline $\begin{array}{l}\text { Mechanical disinfection } \\
\text { and sterilization }\end{array}$ & $\begin{array}{l}\text { Rinse, wipe and } \\
\text { brush away }\end{array}$ & Water, daily cleaning tools & $\begin{array}{l}\text { It is easy to use and can be } \\
\text { removed from the media }\end{array}$ & $\begin{array}{l}\text { Microorganisms cannot } \\
\text { be killed }\end{array}$ \\
\hline
\end{tabular}

\section{Analysis on the status quo of emotional design of consumer-grade disinfectant and sterilizing products}

\subsection{Concept of emotional design}

In the information age, users, while using products, not merely raise their demands for practical functions of products, but wish to interact with products in most cases. The well-known American designer Donald · A Norman came up with the concept of emotional design quite earlier. Norman contends that emotion and cognition work in tandem as consumers relate to products. ${ }^{[1]}$ Emotional design means that designers not merely lay emphasis on the design of product appearance and surface decoration, but attach importance to integrating emotion into the design, so that users can arouse emotional resonance when purchasing products, so as to offer positive experience to users. Emotional design is premised on "stimulus" and "concerns" to form the emotional nine-source matrix of products, specifically as displayed in Figure 1. 


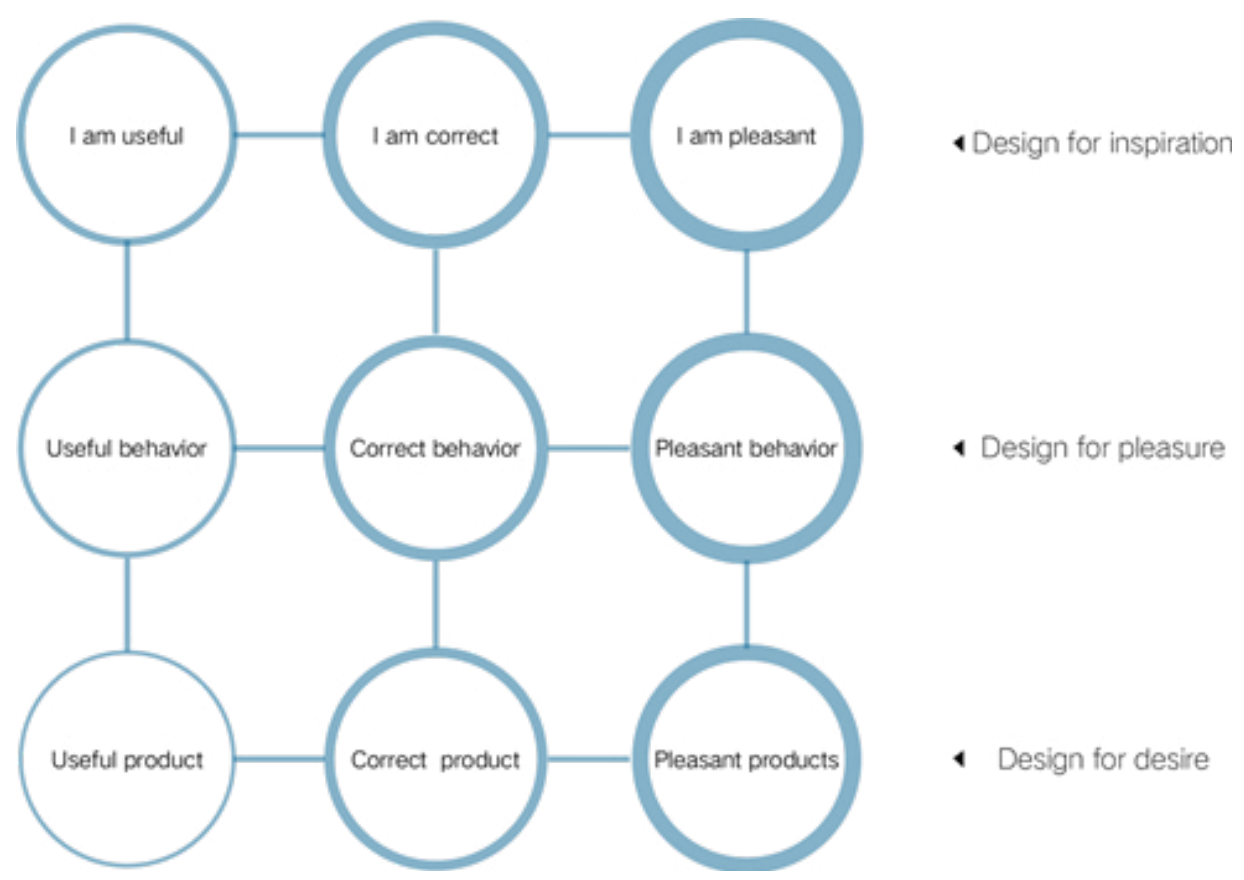

Figure 1. Emotional nine-source matrix (source: made by the author)

Norman categories the user experience of products into three levels from the exterior to the interior: visceral level, behavioral level and reflective level, as presented in Figure 2.

(1) The visceral layer is the user's initial impression of the products, and the design premised on visceral layer is chiefly embodied in the users' sensory experience of the products, such as shape, color, material, technology, texture, etc.

(2) The behavioral layer is the man-machine interaction experience produced by users while using the product, and every step of users' operation is closely linked with users' expectation. As far as the product is concerned, user experience in the behavioral layer includes four aspects: function, performance, reliability, usability and pleasure.

(3) The reflective layer is the emotional reaction of users while using products, which is chiefly embodied in emotional experience, and is more profound than the sensory and interactive experience mentioned above. Proceeding from the reflective level, it is essential to clearly locate the target users, fully learn about the cognitive behavioral habits of users, and make rational use in the design, so that users can emotionally resonate with products and raise a sense of belonging to products while use, including emotional design, brand strategy design and personalized design ${ }^{[2]}$

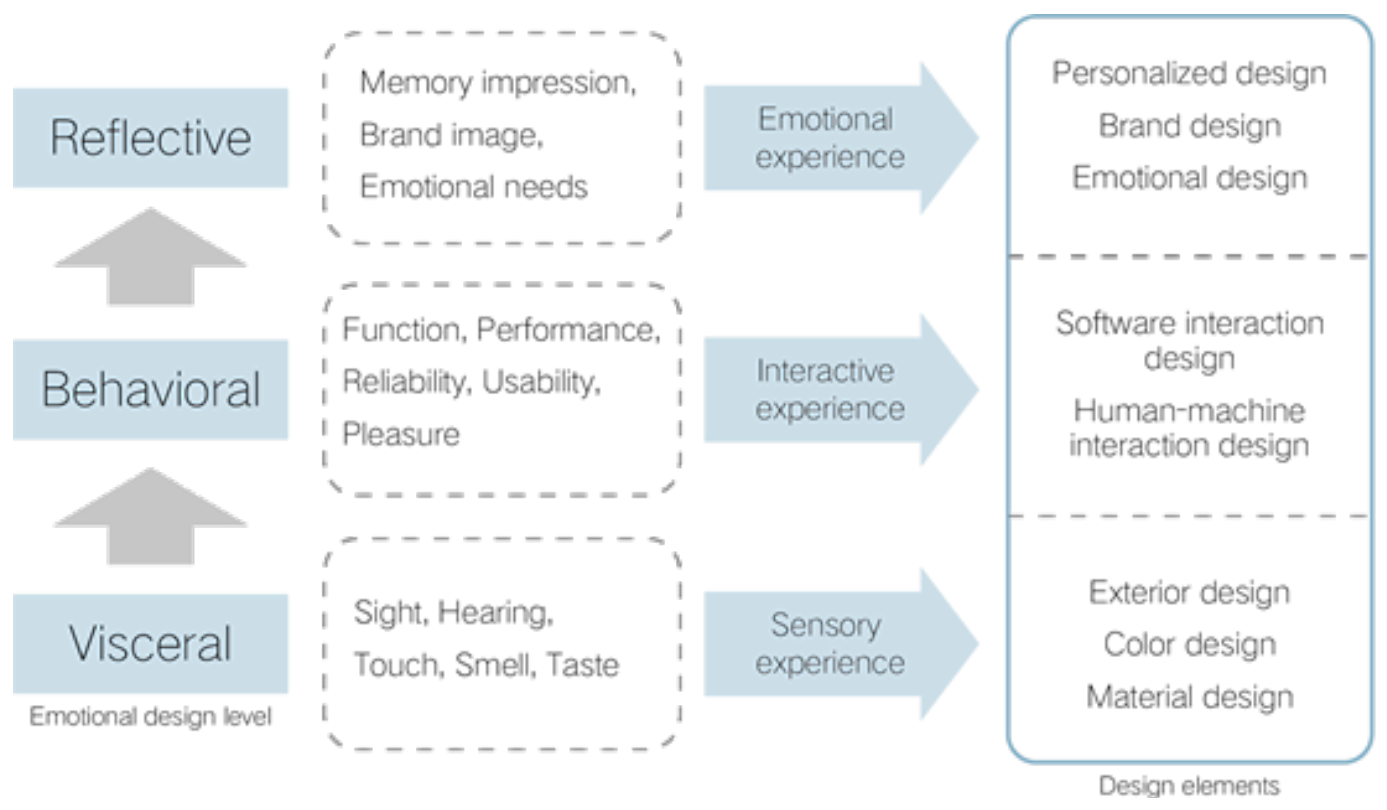

Figure 2. Analysis model of emotional design (source: made by the author) 


\subsection{Analysis of development status of emotional design of consumer-grade disinfectant and sterilizing products}

After the COVID-19 epidemic, the general public's health awareness of disinfection and sterilization has been raised, and the demand for disinfectant and sterilizing products has also increased along with it. Disinfectant and sterilizing products boast enormous market potential. Currently, the common disinfectant and sterilizing products on the market are generally those with chemicals, ultraviolet rays or high-temperature steam as the medium. In the passing years, as there exist numerous categories of disinfection and sterilization objects and different requirements have been raised, numerous types of disinfectant and sterilizing products in the disinfection and sterilization market come into being based on the needs of users and different disinfection and sterilization objects. For instance: electric disinfection mop, clothes disinfection machine, disinfector for baby products, toothbrush disinfector, household ultraviolet disinfection lamp, toilet sterilizer. To explore users' needs for different functions, a questionnaire survey was carried out among 120 users, as presented in Figure 3. The surveyed users hold that the places that require disinfection and sterilization in their homes are living room, porch, bedroom, bathroom, kitchen and balcony in turn. Besides, $35 \%$ of users call for harmless disinfectant and sterilizing products, $21.67 \%$ wish disinfectant and sterilizing products to look beautiful, and $15.83 \%$ and $11.67 \%$ expect disinfectant and sterilizing products to be efficient and intelligent.

The most disinfected place in the home

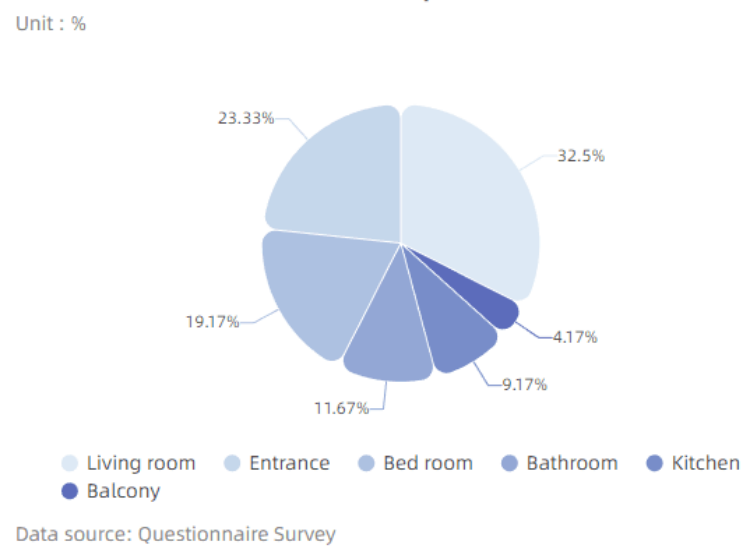

Demand for killing products

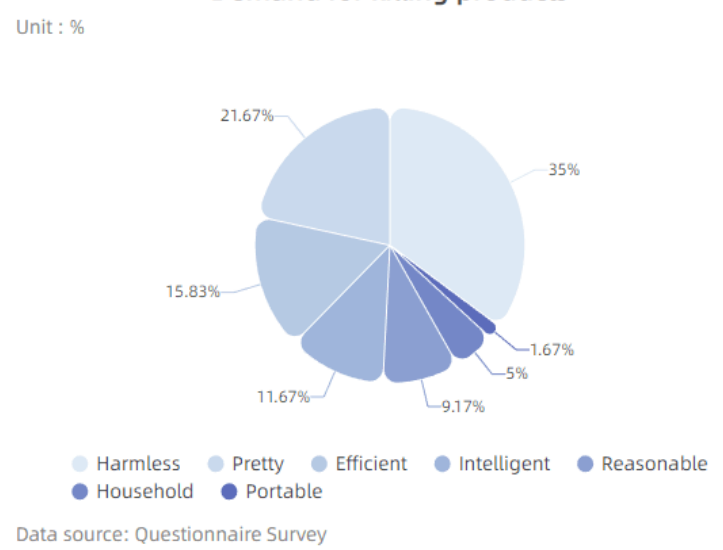

Figure 3. User survey statistics (source: made by the author)

Based on the analysis model of emotional design, upon data investigation, this thesis details the cases of consumergrade disinfectant and sterilizing products at the forefront of the market, with a view to explore the development status of designing consumer-grade disinfectant and sterilizing products, as demonstrated in Table 2.

Through the above five cases of consumer-grade disinfectant and sterilizing products with different functions, this thesis sums up the design status of consumer-grade disinfectant and sterilizing products at three levels of emotional design. On the visceral layer, most of the materials are made of smooth materials with a good touch; the color is white, which represents cleanliness and neatness, and black or gray with a sense of science and technology; based on the use, the size is small and portable. Home-style products are easily considered and the scope of application will expand accordingly. On the behavioral level, the use scenes determine the difference in functionality. No matter what purpose of disinfectant and sterilizing products, they are designed to be as close as household products in respect of use mode and appearance, but the comfort of use is far less than other household products; while ensuring the disinfection and sterilization effect, it is also required to ensure that the harm to human body is minimized. On the reflective level, most products attempt to integrate into the home living environment from the product impression, but after all, they are professional products to some extent and still somewhat incompatible with the home environment; however, products with good disinfectant and sterilizing effect will give people a sense of trust and security; products with exposed functions will give users a sense of alienation. Currently, consumer-grade disinfectant and sterilizing products on the market are gradually transitioning from the behavioral level to the reflective level, and some products are devoted to becoming a good partner for people in their cleaning work. 
Table 2. Analysis of emotional design of consumer-grade disinfectant and sterilizing products

\begin{tabular}{|c|c|c|c|c|}
\hline Product & Picture & Analysis of visceral layer & $\begin{array}{c}\text { Analysis of behavioral } \\
\text { layer }\end{array}$ & $\begin{array}{c}\text { Analysis of reflective } \\
\text { layer }\end{array}$ \\
\hline $\begin{array}{l}\text { APIX INTL } \\
\text { high-temperature } \\
\text { steam mop }\end{array}$ & & $\begin{array}{l}\text { White and gray, with a simple and } \\
\text { fashionable shape. }\end{array}$ & $\begin{array}{l}\text { It is easy to use, can be } \\
\text { stored upright, does not } \\
\text { occupy space, steam } \\
\text { sterilizes the ground at } \\
\text { high temperature, and } \\
\text { disinfectants can be added. }\end{array}$ & $\begin{array}{c}\text { The overall impression } \\
\text { is in line with the } \\
\text { home environment, } \\
\text { with a sense of trust, } \\
\text { security and lack of } \\
\text { affinity }\end{array}$ \\
\hline $\begin{array}{l}\text { Intelligent hand } \\
\text { washer }\end{array}$ & $\widehat{A}$ & $\begin{array}{l}\text { White and transparent materials, } \\
\text { with a simple, compact and } \\
\text { convenient shape }\end{array}$ & $\begin{array}{l}\text { Intelligent induction } \\
\text { spraying can be applied } \\
\text { in all types of scenes with } \\
\text { high efficiency. }\end{array}$ & $\begin{array}{l}\text { The use is worry-free } \\
\text { and convenient, with } \\
\text { a sense of ritual and } \\
\text { security }\end{array}$ \\
\hline $\begin{array}{l}\text { Philips } \\
\text { ultraviolet } \\
\text { disinfection } \\
\text { cabinet }\end{array}$ & & $\begin{array}{l}\text { Large size, heavy weight, white } \\
\text { color, stainless steel inner wall and } \\
\text { heavy shape. }\end{array}$ & $\begin{array}{l}\text { Intelligent one-button } \\
\text { disinfection, large volume, } \\
\text { and all types of items can } \\
\text { be applied }\end{array}$ & $\begin{array}{l}\text { There is a sense of } \\
\text { disobedience with the } \\
\text { home environment, a } \\
\text { sense of security, trust, } \\
\text { and a lack of affinity }\end{array}$ \\
\hline $\begin{array}{c}\text { HOSHOM } \\
\text { fruit and } \\
\text { vegetable } \\
\text { cleaning machine }\end{array}$ & & $\begin{array}{l}\text { White and dark gray, with round, } \\
\text { simple and fashionable shape and } \\
\text { large size }\end{array}$ & $\begin{array}{l}\text { Intelligent, it can remove } \\
\text { residual pesticides besides } \\
\text { bacteria and viruses }\end{array}$ & $\begin{array}{l}\text { The overall impression } \\
\text { is in line with the } \\
\text { home environment, } \\
\text { with a sense of trust, } \\
\text { security and affinity }\end{array}$ \\
\hline $\begin{array}{c}\text { Philips } \\
\text { ultraviolet } \\
\text { disinfection lamp }\end{array}$ & & $\begin{array}{l}\text { Simple and fashionable shape, and } \\
\text { black and gray }\end{array}$ & $\begin{array}{l}\text { It can be remotely } \\
\text { controlled, automatically } \\
\text { closed by tilting, disinfects } \\
\text { the environment in a wide } \\
\text { range, but is harmful to } \\
\text { human skin }\end{array}$ & $\begin{array}{l}\text { The exposed } \\
\text { functional structure is } \\
\text { inconsistent with the } \\
\text { home environment and } \\
\text { has a sense of fear }\end{array}$ \\
\hline
\end{tabular}

\section{Analysis of design trend of consumer-grade disinfectant and sterilizing products}

By analyzing the cases and development status of consumer-grade disinfectant and sterilizing products, it is learned that consumer-grade disinfectant and sterilizing products take on a diversified, intelligent, home-based and emotional trend, as presented in Figure 4. 


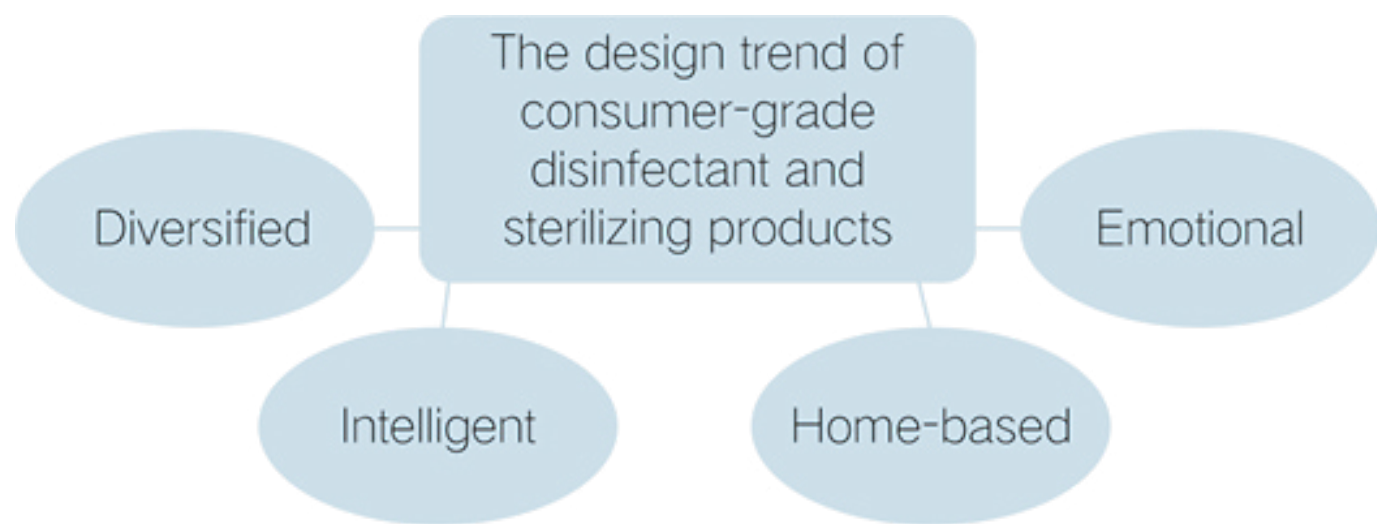

Figure 4. Design trend of consumer-grade disinfectant and sterilizing products (source: made by the author)

\subsection{Diversified}

Thanks to the industrialized development of consumer-grade disinfection and sterilization, the design of consumer products is developing towards multi-object, multi-purpose and multi-scenario. In the first place, multi-object - the users of consumer-grade disinfectant and sterilizing products are no longer confined to cleaners or housewives, the scope of application is expanded in the direction of popularization and generalization; moreover, the objects of disinfection are no longer restricted to the previous concepts, and the daily necessities such as mobile phones, keys, toothbrushes, makeup tools, etc., which appear on the market nowadays, have also turned into the objects of disinfection and sterilization. Besides, multi-purpose - the functions of consumer-grade disinfectant and sterilizing products will definitely be combined with household products in the future, and they are no longer single functional disinfectant and sterilizing products. For instance, the combination of washing machine and disinfectant and sterilizing machine of clothes, the combination of sweeping robot and disinfection machine, etc. Furthermore, multi-scenario - portable, multi-scenario-based disinfectant and sterilizing products will also be one of the main trends of consumer-grade disinfectant and sterilizing products in the future. Diversification is of enormous significance for promoting the functionality and convenience of consumer-grade disinfectant and sterilizing products at the behavioral level.

\subsection{Intelligent}

Influenced by smart home appliances, consumer-grade disinfectant and sterilizing products also take on an intelligent trend. Intelligent technologies such as remote control, temperature recognition and home appliances IoT are increasingly applied to consumer-grade disinfectant and sterilizing products. The combination of consumer-grade disinfectant and sterilizing products and smart cleaning home appliances has created an effective work assistant in people's lives, which increasingly deepens the sense of dependence, trust and even emotional sustenance on consumer-grade disinfectant and sterilizing products, and contributes to enhance the emotional experience of users at the reflective level.

\subsection{Home-based}

The home-based trend of consumer-grade disinfectant and sterilizing products is chiefly embodied in two aspects. Firstly, the disinfectant and sterilizing products have to be integrated into the home environment to lower the feeling of strangeness. When it comes to how to make users feel that the product is a part of the home, it is essential to reinforce the home-base attributes of consumer products from the emotional experience of the reflective layer. The second is to enhance the affinity of disinfectant and sterilizing products. In respect of the current disinfectant and sterilizing products, it is essential to enhance the intimacy with users in the selection of materials, the affinity of shapes and the matching of colors.

\subsection{Emotional}

The realization of functions can't entirely prevent the loss rate of users, and only the emotional demand besides function and technology is precisely the inexorable trend of product development. ${ }^{[3]}$ Emotional design is designed specially for the concerns of users. Among disinfectant and sterilizing products, users not merely attach importance to the effect of disinfection and sterilization, but to the damage of disinfection and sterilization to household products, environment and human body, etc. How to focus on the users' concerns and identify users' feelings of frustration when using products can enable users to enjoy a good use experience and give products a sense of pleasure and security. Emotional consumergrade disinfectant and sterilizing products can arouse users' positive emotions at the reflective level, thus increasing their 
stickiness.

\section{Summary}

Emotional design is essentially intended to enhance the emotional communication and exchanges between products and consumers, and it is an effective way to shape product image and draw consumers' attention. ${ }^{[4]}$ Consumer-grade disinfectant and sterilizing products are consumer-grade products characterized by single function and simple principle. In the disinfection and sterilization industry after the epidemic, it remains a hot issue on how consumer-grade disinfectant and sterilizing products enhance their market competitiveness, and satisfy the needs of users to upgrade their quality of life and maintain a clean and tidy sterile home environment. With reference to the Emotional Design Theory, this thesis builds an analysis model of emotional design for consumer-grade disinfectant and sterilizing products. By exploring the emotional cases of market products, conclusion is drawn that the future design of consumer-grade disinfectant and sterilizing products will develop in a diversified, intelligent, and home-based and emotional trend.

\section{References}

[1] Norman, Donald Arthur. Emotional Design. Translated by Fu Qiufang, Cheng Jinsan. Beijing: Publishing House of Electronics Industry; 2005.

[2] He Tai, Xu Kaiqiang. Research on Product Emotionalization in Interactive Design. Industrial Design. 2017; (12): 6364.

[3] Chen Jing. (2016) Research on Emotional Design of Wearable Devices. Wuhan: Wuhan University of Technology.

[4] Wu Tianyou, Chen Mingqiu. Research on Emotional Design of Small Kitchen Appliances. Industrial Design. 2020; (08): 64-65. 